\title{
Assessment of Seasonal Variation in Water Quality in River Rwizi Using Multivariate Statistical Techniques, Mbarara Municipality, Uganda
}

\author{
Walter Ojok ${ }^{1}$, John Wasswa ${ }^{2}$, Emmanuel Ntambi ${ }^{*}$ \\ ${ }^{1}$ Department of Chemistry, Faculty of Science, Mbarara University of Science and Technology, Mbarara, Uganda \\ ${ }^{2}$ Department of Chemistry, College of Natural Sciences, Makerere University, Kampala, Uganda \\ Email: ${ }^{*}$ mmantambi@must.ac.ug, *emmantambi@must.yahoo.com
}

How to cite this paper: Ojok, W., Wasswa, J. and Ntambi, E. (2017) Assessment of Seasonal Variation in Water Quality in River Rwizi Using Multivariate Statistical Techniques, Mbarara Municipality, Uganda. Journal of Water Resource and Protection, 9, 83-97.

http://dx.doi.org/10.4236/jwarp.2017.91007

Received: December 6, 2016

Accepted: January 22, 2017

Published: January 25, 2017

Copyright $\odot 2017$ by authors and Scientific Research Publishing Inc. This work is licensed under the Creative Commons Attribution International License (CC BY 4.0).

http://creativecommons.org/licenses/by/4.0/

\begin{abstract}
Assessment of seasonal variations in surface water quality characteristics is an essential aspect for evaluating water pollution due to both natural and anthropogenic influences on water resources. In this study, temporal variations of water quality in river Rwizi section within Mbarara municipality, Uganda, were assessed using multivariate statistical methods. This river section is a major source of water for the inhabitants of Mbarara municipality. Water samples from five sites were analyzed for physicochemical parameters such as $\mathrm{pH}, \mathrm{EC}$, turbidity, temperature, TSS, TDS, alkalinity, salinity, colour, $\mathrm{NH}_{3}-\mathrm{N}$, $\mathrm{SO}_{4}^{2-}$, total hardness, $\mathrm{BOD}, \mathrm{COD}, \mathrm{DO}, \mathrm{Ca}, \mathrm{Mg}, \mathrm{Fe}$, and $\mathrm{Mn}$. About $50 \%$ of sites recorded colour above $800 \mathrm{Pt} \mathrm{Co}, 60 \%$ of sites recorded turbidity above maximum permissible limit of $100 \mathrm{mg} / \mathrm{l}$, attributable to erosion and mineral matter. $\mathrm{pH}$ for dry season ranged between 6.5 and 8.5 whereas for rainy season was below 6.0. All study sites recorded total Fe above $0.3 \mathrm{mg} / \mathrm{l}$ and $\mathrm{Mn}$ below $0.5 \mathrm{mg} / \mathrm{l}$, attributable to chemical weathering of host rock materials as well as from industrial effluent. About $60 \%$ of sites recorded COD above 100 $\mathrm{mg} / \mathrm{l}, 40 \%$ and $80 \%$ of study sites showed BOD above $50 \mathrm{mg} / \mathrm{l}$ in dry and rainy seasons respectively. Hardness ranged between 50 and $100 \mathrm{mg} / \mathrm{l}$ indicating that the water is moderately soft. Colour, turbidity, alkalinity, TSS, TDS, salinity, $\mathrm{pH}$, hardness, $\mathrm{Fe}, \mathrm{Mn}, \mathrm{NH}_{3}-\mathrm{N}, \mathrm{BOD}, \mathrm{COD}$, and $\mathrm{DO}$ were higher in rainy season, as a result of erosion, discharge of domestic and industrial waste. $\mathrm{Mg}, \mathrm{Ca}$, and $\mathrm{SO}_{4}^{2-} \quad$ were higher during dry season due to high evaporation of water from the river. PCA/FA determined that $81.2 \%$ of the total variance was explained by the first factor for the dry season and $69.2 \%$ for rain season. These results revealed that water pollution resulted primarily from domestic waste water, agricultural runoff and industrial effluents.
\end{abstract}




\section{Keywords}

Principal Component Analysis, Factor Analysis, River Rwizi, Physico-Chemical, Water Pollution

\section{Introduction}

Access to clean and safe water and improved sanitation facilities and practices are pre-requisites to a healthy population and therefore have a direct impact on the quality of life and productivity of the population. Thus, information on water quality and pollution sources in such water bodies is important for the implementation of sustainable water use management strategies [1]. For effective maintenance of water quality through appropriate control measures, continuous monitoring of a large number of quality parameters is essential [2]. In addition, due to seasonality and regionality of river water, assessing spatial-temporal variations has become an important aspect of river water quality at a watershed level as an important aspect for the physical and chemical characterization of aquatic environments [3]. The studies in Uganda have shown that most water resources are easily contaminated from anthropogenic activities especially in urban areas [4] [5] [6] [7] [8].

Hence, it is necessary to obtain information on the temporal variation of physico-chemical characteristics of water resources in order to provide baseline information for a monitoring program for water resources in Uganda. For instance, information on temporal variation in physico-chemical characteristics of water resources can help in deciding on the type of water treatment process to be adopted [9] [10].

Investigations of water quality often require that numerous variables be examined simultaneously [11]. Infact, in the recent decades, river water quality monitoring by measurement of numerous water quality parameters has increased tremendously. Since the number of variables involved is greater than two, application of multivariate statistical analysis techniques gives simpler and more easily interpretable results for the evaluation of the observed water quality data [12] [13] [14] [15] [16]. Hence, the application of multivariate statistical techniques such as principal component analysis, and factor analysis have increased tremendously in the recent years for analysing water quality data and drawing meaningful information. These techniques allow the identification of possible sources of pollutants that influence water systems. They also offer a valuable tool for reliable management of water resources as well as rapid solution for pollution problems [16] [17]. The River Rwizi section was selected for water quality evaluation because it is a major source of water for the inhabitants of Mbarara Municipality. The river Rwizi water catchment has been studied by several researchers [18] [19]. The studies in Uganda have shown that most water resources are easily contaminated from anthropogenic activities especially in urban areas [8]. However, no studies have been reported on the temporal varia- 
tion of river Rwizi. Therefore, this study was to evaluate the seasonal variation of water quality of river Rwizi section in Mbarara Municipality.

\section{Materials and Methods}

\subsection{Location of Study Area}

The study area is located in Mbarara Municipality found in Mbarara District, south western Uganda (Figure 1). The study section of the river is about $15 \mathrm{~km}$ long. It lies between co-ordinates $0^{\circ} 374.69^{\circ} \mathrm{S}, 030^{\circ} 372.76^{\circ} \mathrm{E}$, and $0^{\circ} 366^{\prime} 30.32^{\circ} \mathrm{S}$, $030^{\circ} 41^{\prime} 51.13^{\circ} \mathrm{E}$. The Rwizi catchment covers a total area of $2521 \mathrm{~km}^{2}$. The altitude varies from 1261 m.a.s.l at the outlet to 2168 m.a.s.l at the very northern

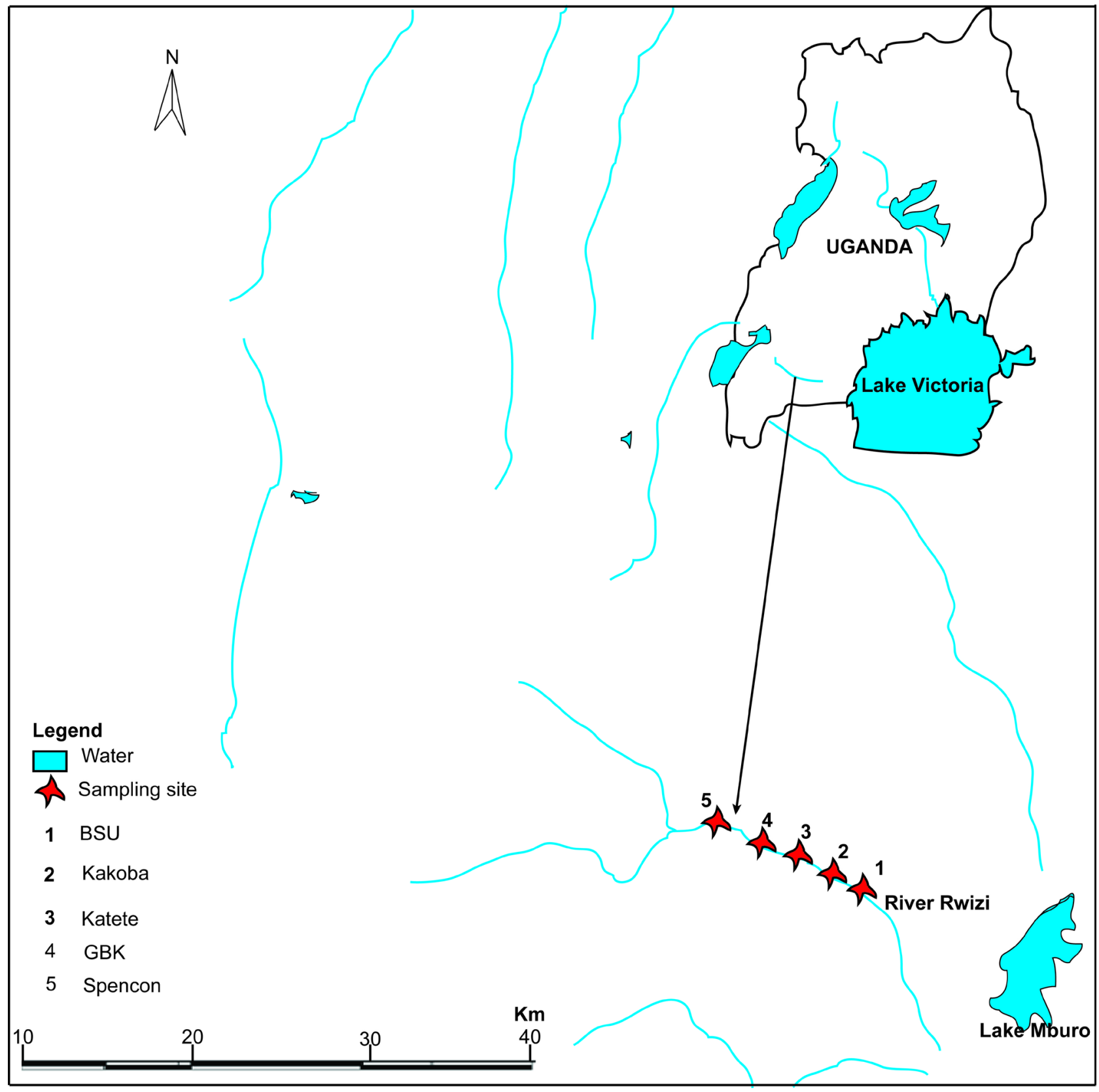

Figure 1. The study section of River Rwizi in Mbarara Municipality. 
part of the catchment [19]. River Rwizi originates from the Buhweju hills in south western Uganda and has various tributaries. It traverses over ten districts including Bushenyi, Ntungamo, Sheema, Mbarara, Kibingo, Isingiro, Kiruhura, Lyantonde, Rakai and Buhweju among others. It eventually pours its waters into Lake Victoria via the network of the Kooki lakes (Mburo, Kachera, Nakivale, and Kijanebarola, among others) system. The river serves two Ramsar sites of $\mathrm{L}$. Mburo/Nakivale wetland system and Sango Bay wetland forests. The river is a major source of water for domestic, agricultural and industrial activities in South western Uganda [19].

\subsection{Water Sample Collection}

Water samples were collected from five sampling sites of river Rwizi for dry and rainy seasons. The collected samples were stored in a $1.5 \mathrm{~L}$ polyethylene plastic bottle cleaned with metal free soap, rinsed many times with deionised water and then soaked in acidified potassium dichromate (VI) for 24 hours in order to remove any other contaminants that were not removed by soap and then rinsed again with deionised water. Sampling site selection criteria included natural conditions as well as catchments with human activities.

Site 1 (BSU) represents the influence of activities in the Rwizi catchment within Mbarara municipality on the quality of the river Rwizi water. Site 2 (Kakoba), site 3 (Katete), site 4 (GBK) are affected by a variety of wastes from residential, agricultural, river sand mining, brick making and industrial activities. Site 5 (Spencon) represents the water entering the Municipality.

\subsection{Analysis of River Rwizi Water}

The selected water quality parameters were analysed using methods that were adopted from various textbooks and Manuals of analytical chemistry [20] [21] [22].

The temperature, $\mathrm{pH}$, electrical conductivity (EC), total dissolved solid (TDS) and salinity of the water samples were measured on site by a thermometer, $\mathrm{pH}$ meter, EC, CIBA-CORING conductivity meter, TDS and salinity using the multi-parameter water quality monitoring instrument respectively [20]. Dissolved oxygen (DO) was determined by DO bottle method, Biochemical oxygen demand $\left(\mathrm{BOD}_{5}\right)$ by the Winkler-azide method and chemical oxygen demand (COD) by using DR/2010 spectrophotometer respectively [20].

Total suspended solids (TSS) was determined by using the photometric method, colour by the platinum-cobalt standard method, and ammonia-nitrogen $\left(\mathrm{NH}_{3}-\mathrm{N}\right)$ by the Nessler method [22]. Sulphate was determined by using the Sulfaver-4-method, DR 2010 spectrophotometer [20]. Alkalinity was determined by titration using standard sulphuric acid [21], total hardness by titration with standard ethylene diamine tetra acetic acid and turbidity using HACH 2100AN turbidimeter [20]. $\mathrm{Ca}$ and $\mathrm{Mg}$ were determined by titration with ethylene diamine tetra acetic acid [20]. Flame atomic absorption spectrophotometer (Perkin Elmer model 2380) was used to determine Fe and Mn [21]. 


\section{Statistical Methods}

Mathematical, statistical calculations and graphical presentations were performed using Statistical Software for Social Sciences (SPSS) 16.0, PAST, Adobe Illustrator 8.0 and Microsoft Excel 2007 softwares. The physico-chemical results were subjected to normality tests by fitting them with normal and lognormal distributions, on the premise that the variables were independent and identically distributed over the study area and sampling period.

\subsection{Principal Component Analysis}

Principal component analysis (PCA) is defined as an orthogonal linear transformation that transforms the variables to a new coordinate system such that the greatest variance by any projection of the variables comes to lie on the first coordinate (called the first principal component), the second greatest variance on the second coordinate, and so on [23]. PCA is designed to transform the original variables into new, uncorrelated variables, called the principal components, which are linear combinations of the original variables [24]. A principal component provides information on the most meaningful parameters, which describes a whole data set, affording data reduction with a minimum loss of the original information [25] [26].

\subsection{Factor Analysis}

Factor analysis (FA) is a multivariate statistical technique that can be utilized to examine the underlying patterns or relationship for a large number of variables and summarize information in a smaller set of factors or components for prediction purposes [15]. The main purpose of factor analysis is to reduce the contribution of less significant variables and to simplify even more the data structure coming from the PCA. As a result, a small number of factors will usually account for approximately the same amount of information as do the much larger set of original observations [25] [26].

Classification of factor loading is thus strong, moderate, and weak; corresponding to absolute loading values of greater than $0.75,0.75-0.50,0.5-0.3$ respectively [27]. The largest factor loading either positive or negative, suggest the meaning of the dimensions. Positive factor loading shows that the contribution of the variables increases with the increasing factor loading in dimension. Negative factor loading on the other hand indicates a decrease of contribution of the variable with increasing loading [12] [28].

\section{Results and Discussion}

\subsection{Seasonal Variations of Water Quality Parameters of River Rwizi}

The mean temporal variation in concentration of physico-chemical parameters are presented in Figure 2 and Figure 3. The trends of seasonal variation are represented by Box and Whisker plots in Figure 4. 


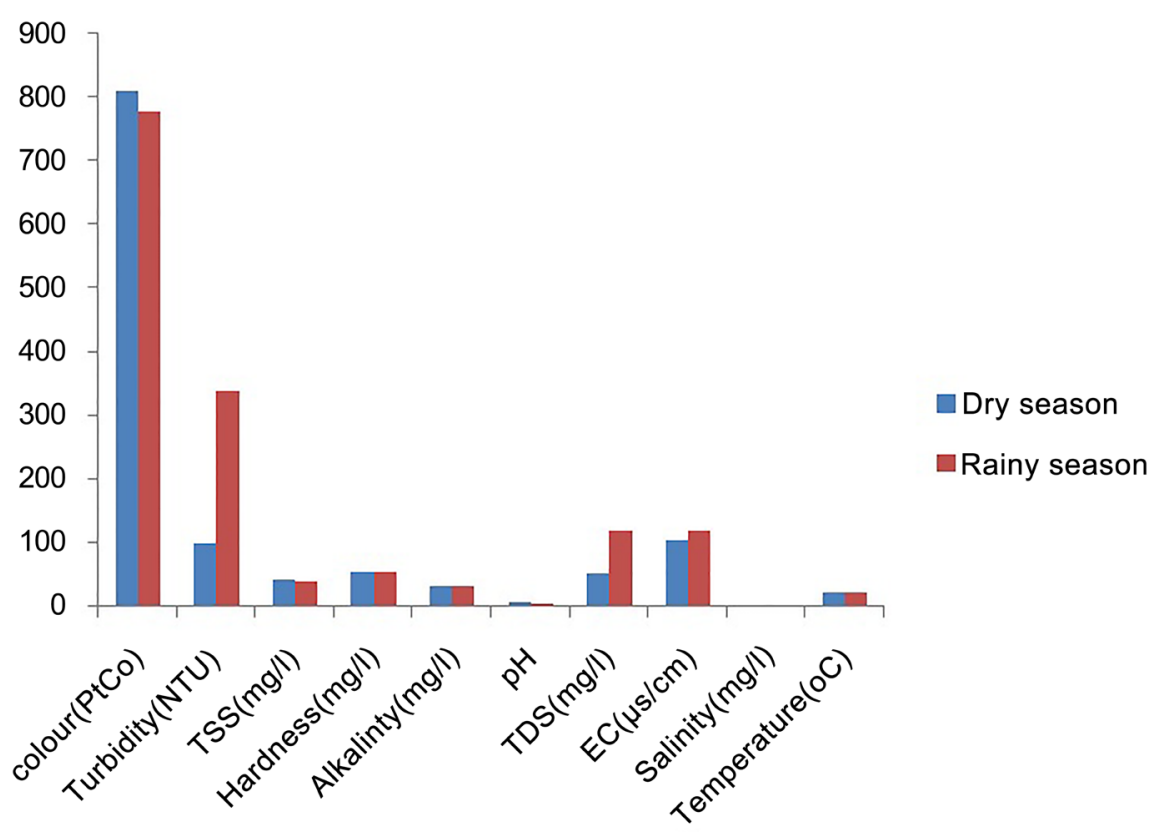

Figure 2. Seasonal variation in mean concentrations of physical parameters.

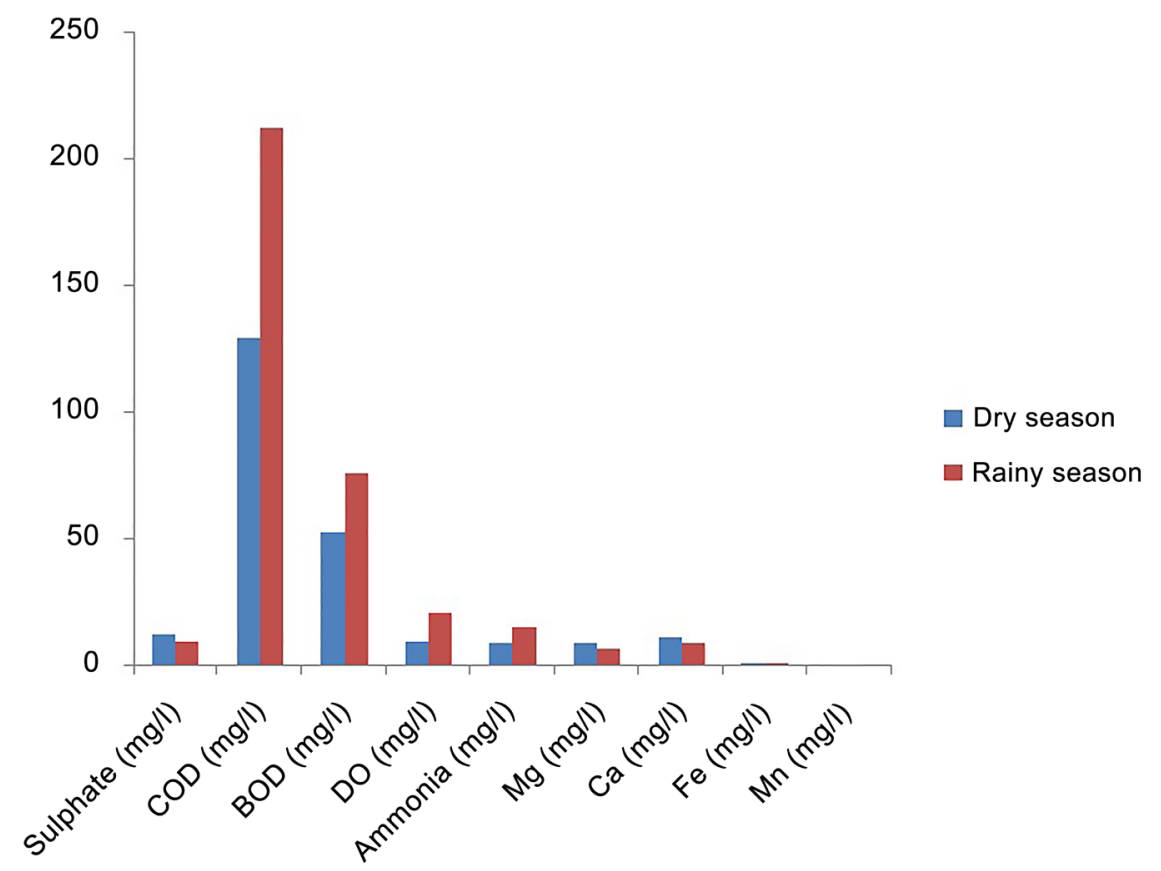

Figure 3. Seasonal variation in mean concentrations of chemical parameters.

The average colour was higher in the dry season as compared to the rainy season (Figure 2). The highest colour measurement was recorded in August while the lowest was in May (Figure 4). The mean turbidity, TSS and TDS were higher in rain season as compared to dry season (Figure 2). The highest turbidity measurement was recorded in August while the lowest was in May (Figure 4(s)). The highest TSS measurement was recorded in August while the lowest was in May. The highest TDS measurement was recorded in August while the lowest was in October (Figure 4(0)). 


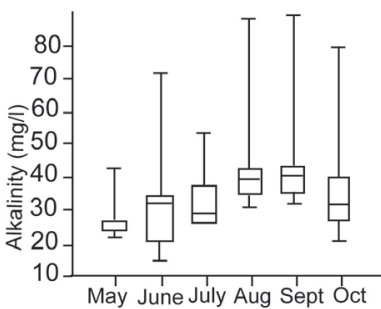

(a)

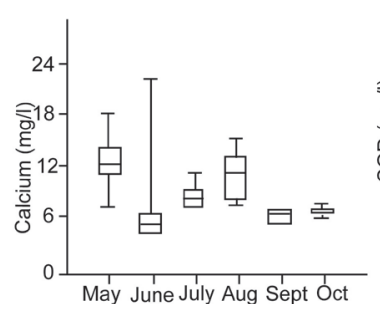

(d)

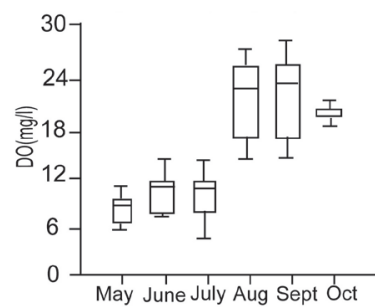

(g)

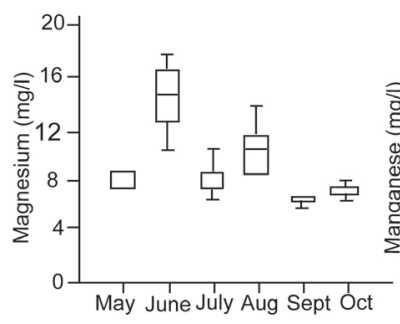

(j)

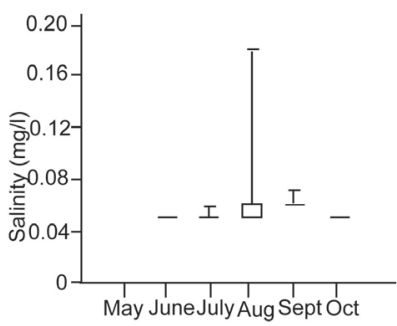

(m)

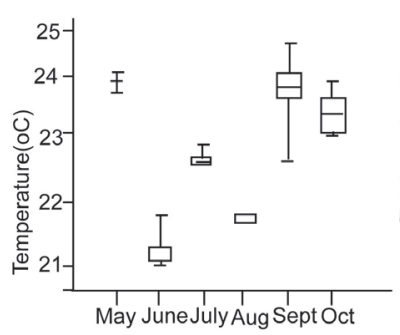

(p)

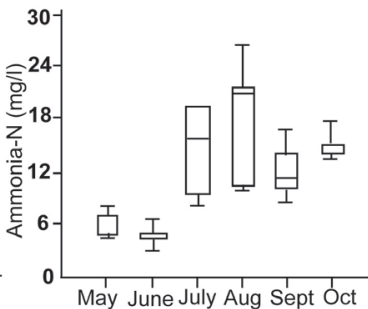

(b)

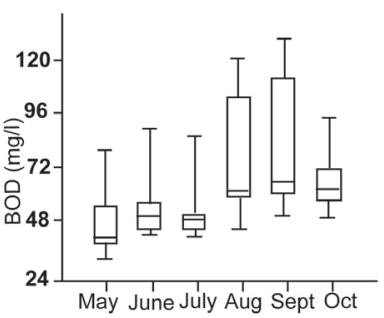

(c)

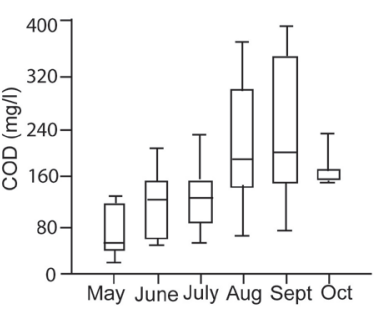

(e)

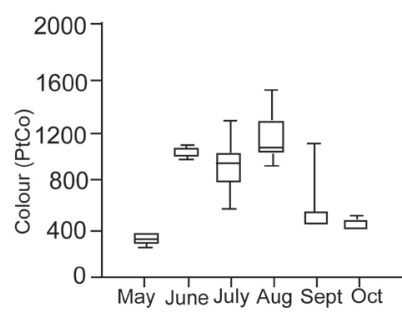

(f)

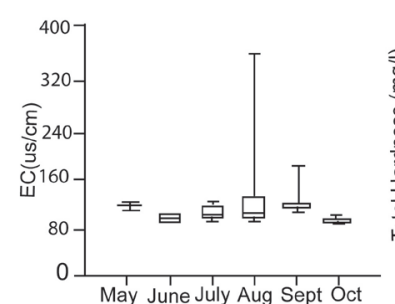

(h)

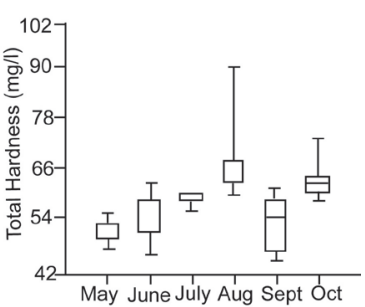

(i)

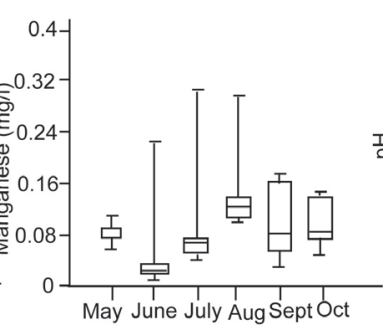

(k)

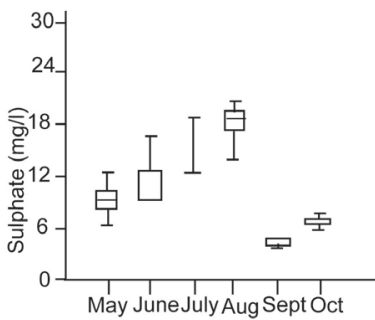

(n)

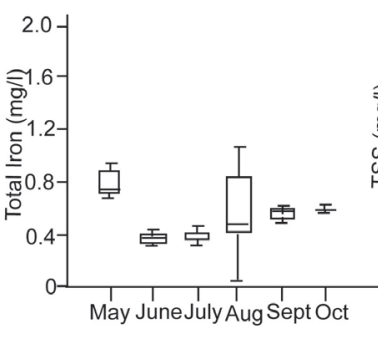

(q)

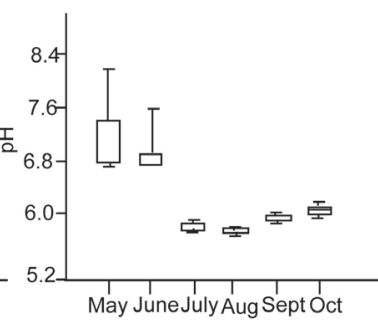

(1)

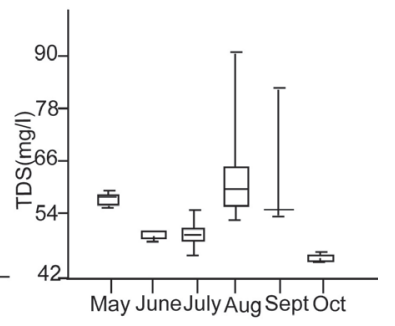

(o)

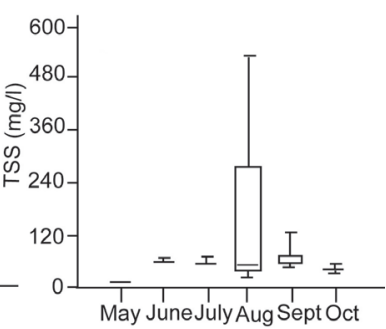

(r) 


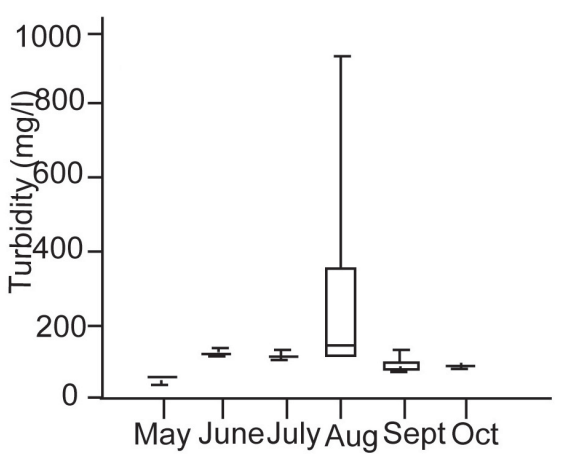

(s)

Figure 4. The trend of seasonal variation of water quality parameters in the River Rwizi section in Mbarara municipality.

The colour, turbidity, TSS, and TDS measurements were higher in the rainy season because of the soil erosion of the prepared agricultural fields with loose top layer of the soil. Also, debris falling off due to the wind and rainfall could have contributed particles to the river water. The increased agricultural land use and built up intensity in the river catchment at the onset of the rainy season also contributed to variation in these parameters. In addition, the increased water volume in the river may have resuspended the bottom sediments due to rapid flow rate of the river water.

Mean salinity and E.C were higher in the rainy season (Figure 2). The highest E.C measurement was recorded in August and May while the lowest occurred in June and October (Figure 4(h)). However, there was a slight variation in salinity measurement during the six months of the study (Figure $4(\mathrm{~m})$ ). The higher E.C and salinity recorded in the rainy season also coincided with the time of release of industrial effluents and increased waste water amount that entered the river at the onset of the rainy season. In addition, some mineralization of the rock materials in contact with the river water might have occurred, especially due to lowered $\mathrm{pH}$ in the rainy season. These might have led to increase in salinity and E.C measured. E.C qualitatively reflects the status of inorganic pollution. There are reports on several other urban rivers indicating similar results [10] [29] [30].

Total hardness, $\mathrm{NH}_{3}-\mathrm{N}$, and alkalinity (Figure 2) were slightly higher in rainy season than in the dry season. The highest alkalinity measurements were recorded in August and September while the lowest were in May and June (Figure 4(a)). $\mathrm{NH}_{3}-\mathrm{N}$ was highest in July and August (Figure 4(b)) while hardness was highest in August and October (Figure 3). These were due to effluent discharge at the start of the rainy season. Besides, there was increased sewage, domestic waste, and animal excreta, during the rainy season. The presence of ammonia in the river water, during the dry season was attributed to domestic pollution. Hence the high concentration of $\mathrm{NH}_{3}-\mathrm{N}$ observed during the rainy season indicated the influence of urban domestic waste and raw sewage on River Rwizi.

The mean total iron and manganese concentration were higher in the rain season (Figure 3). The highest concentration of iron was recorded in May and 
August while the lowest were in June and July (Figure 4(q)). The highest concentration of manganese was registered in September while the lowest was in June (Figure $4(\mathrm{k})$ ). The iron and manganese was attributable to waste water discharge, effluents from industries and rain water runoff in Mbarara municipality, and mineralisation of rocks thereby releasing metal ions into the river.

The average COD, BOD, and DO value were higher in the rain season than in the dry season (Figure 3). The highest COD was recorded in September while the lowest was in May (Figure 4(e)). The highest BOD measurement was recorded in August while the lowest was in May (Figure 4(c)). The highest DO measurements were recorded in August and September while the lowest was in May (Figure $4(\mathrm{~g})$ ). The mean $\mathrm{COD}$ and $\mathrm{BOD}_{5}$ were higher in the rainy season mainly due to the high effluent discharge from storm drainage, factories and urban settlements. In addition, the higher COD measurement during the rainy season was partly due to increased inflow of organic matter into the river. The high concentration of organic matter might have favoured the proliferation of microbes. The increase in population of microbes means high concentration of oxygen was consumed during their aerobic respiration as a result of the breakdown of organic matter leading to high BOD [31]. The trend for dissolved oxygen was due to the rapid flow rate of water during the rainy season. In addition, increased photosynthetic activity of aquatic plants and bacteria due to the increase in temperature, led to high DO. There are reports from other studies on several other river basins [10] [29] [31].

The average $\mathrm{pH}$ (Figure 2) was higher in dry season than in the rainy season. The highest $\mathrm{pH}$ measurement was recorded in May while the lowest was in July (Figure 4(1)). The $\mathrm{pH}$ of the water samples were below 7, indicating that the water was acidic. This may be attributed to the dissolved acidic gases, oxidation of sulphur compounds and hydrolysis of cations with high charge densities. Generally, the $\mathrm{pH}$ values in this study were indicative of good water quality. The average $\mathrm{pH}$ values were within the acceptable range of regulatory limits [32] [33] [34] except for the rain season which was slightly more acidic than the limits.

The variation in mean temperature (Figure 2) is approximately similar in the two different seasons, although the average temperature was slightly higher in the rainy season. The highest temperatures were observed in May and September (Figure $4(\mathrm{p})$ ). The slightly high temperature recorded during the rainy season could be attributed to the position of the sun over head the equator during September October period of the study. The phenomenon of water land breeze could also account for this variation in temperature.

The highest concentration of calcium and magnesium were recorded in the dry season (Figure 3). Whereas the highest concentration of calcium was recorded in May (Figure 4(d)), that of magnesium was highest in June (Figure $4(j))$ and lowest concentrations were in September for both metals. Similarly, mean concentration of $\mathrm{SO}_{4}^{2-}$ was higher in the dry season (Figure 3). The highest concentration of $\mathrm{SO}_{4}^{2-}$ was recorded in August while the lowest was in September (Figure $4(\mathrm{n})$ ). These mainly arose from mineralization processes of 
the carbonate containing rock materials in contact with water, for example dolomite and calcite [29]. In addition evaporation of water during the dry season led to increase in concentration of calcium, magnesium and sulphate.

\subsection{Principal Component Analysis}

PCA/FA was performed on the normalised data sets containing 19 variables, separately for the two seasons of the year, in order to identify important seasonal water quality parameters [29] [31]. PCA of the two data sets yielded two principal components with Eigen values greater than one (Table 1).

For each season two factors were obtained through the FA performed on the principal components. In addition, scree plots for both dry and rain seasons revealed that the water quality data sets consist of two component system (Figure $5)$.

Table 1. Factor loading values and explained variance of quality parameters of river Rwizi for the two seasons.

\begin{tabular}{|c|c|c|c|c|}
\hline & Dry season & & ainy seaso & \\
\hline parameters & factor 1 & factor 2 & factor 1 & factor 2 \\
\hline colour & 0.9841 & -0.1775 & 0.9976 & 0.0691 \\
\hline turbidity & 0.9865 & -0.1637 & -0.9761 & 0.2176 \\
\hline TSS & 0.9997 & -0.1637 & 0.9994 & 0.0345 \\
\hline T-Hardness & 0.8648 & -0.0238 & -0.5793 & 0.8151 \\
\hline T-Iron & -0.9995 & 0.5021 & 0.263 & 0.9648 \\
\hline Alkalinity & 0.9985 & 0.0324 & -0.6876 & -0.7261 \\
\hline COD & 0.9889 & -0.0546 & -0.424 & -0.9056 \\
\hline BOD & 0.8903 & 0.1484 & -0.4162 & -0.9093 \\
\hline DO & 0.9997 & -0.4555 & -0.6324 & -0.7746 \\
\hline $\mathrm{pH}$ & -0.689 & 0.0226 & 0.9934 & 0.1148 \\
\hline TDS & -0.9968 & -0.7248 & -0.8188 & -0.5741 \\
\hline E.C & -0.94 & 0.0795 & -0.9988 & -0.0492 \\
\hline salinity & -0.9995 & 0.3411 & -0.9787 & -0.2053 \\
\hline temperature & -0.8143 & 0.0316 & 0.9308 & -0.3654 \\
\hline $\mathrm{NH} 3-\mathrm{N}$ & 0.4175 & 0.5804 & -0.7406 & 0.6719 \\
\hline sulphate & 0.7972 & 0.9087 & -0.9233 & 0.3842 \\
\hline $\mathrm{Mg}$ & 0.518 & 0.6038 & -0.925 & 0.3799 \\
\hline $\mathrm{Ca}$ & -0.9973 & -0.8554 & -0.9312 & 0.3646 \\
\hline $\mathrm{Mn}$ & 0.9448 & 0.0737 & -0.9853 & 0.1708 \\
\hline Eigen value & 15.4346 & 0.3275 & 13.1508 & 5.8492 \\
\hline Variance (\%) & 81.235 & 18.765 & 69.215 & 30.785 \\
\hline Cummulative (\%) & 81.235 & 100 & 69.215 & 100 \\
\hline
\end{tabular}




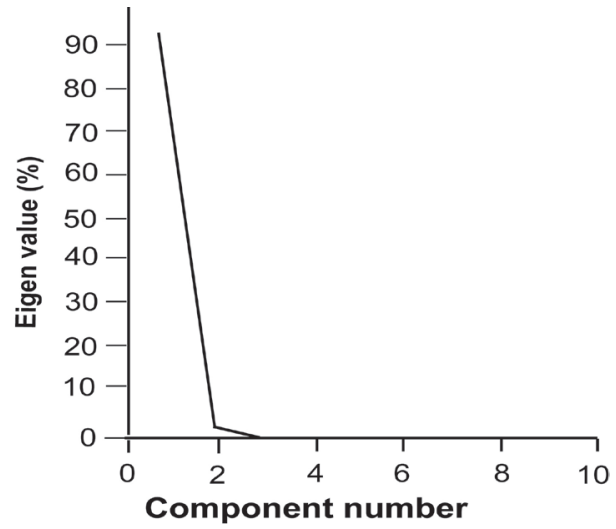

(a)

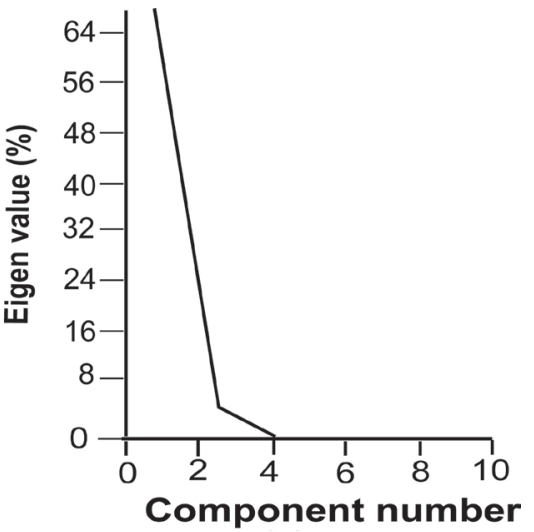

(b)

Figure 5. (a) Scree plot showing Eigen values and principal components for rain season; (b) scree plot showing Eigen values and principal components for dry season.

The factor loadings were used to determine the relative importance of a water quality variable compared to other water quality parameters in a factor and do not reflect the importance of the factor itself [29]. Classification of the factor is thus: "strong", "moderate", and "weak", corresponding to absolute loading values of greater than $0.75,0.75-0.50,0.5-0.30$, respectively [27]. Therefore, each water quality parameter with a strong correlation coefficient value greater than 0.75 was considered to be a significant parameter contributing to seasonal variations of the water quality in River Rwizi.

Based on the correlation matrix of variables, the first two factors with Eigen values greater than 1 explained about $100 \%$ of the total variance. In the dry season, Factor 1 accounted for about $81.2 \%$ of the total variance. It was highly correlated with major physico-chemical variables; colour, turbidity, TSS, total hardness, alkalinity, COD, BOD, DO, TDS, EC, salinity, temperature, sulphate, Ca, $\mathrm{Fe}$, and $\mathrm{Mn}$. Factor 2 accounted for about $18.8 \%$ of the total variance. This included $\mathrm{pH}, \mathrm{NH}_{3}-\mathrm{N}$, and $\mathrm{Mg}$. The $\mathrm{Mg}, \mathrm{Ca}, \mathrm{Fe}, \mathrm{Mn}$, called salinity factors, represented the total salt concentration. This was attributed to evaporation and mineralisation of host rock materials. BOD and COD showed strong factor loadings and are important parameters that accounted for water quality variations for the dry season. Dissolved $\mathrm{SO}_{4}^{2-}$ with positive factor loading was as a result of oxidation of organic and inorganic sulphur compounds in the aquatic environment. Hence, the seasonal variations of $\mathrm{SO}_{4}^{2-}$ were attributable to changes in the intensity of weathering process.

The colour, turbidity, and TSS with positive strong factor loading values contributed to water quality variations in the two seasons. This has the meaning that the clarity of River Rwizi water was not only dependent on erosion but also on geochemical processes/trophicity factors. This was because there was no soil erosion during the dry season.

In the rain season, Factor 1 accounted for about $69.2 \%$ of the total variance. It was highly correlated with major physico-chemical variables: colour, turbidity, TSS, TDS, E.C, $\mathrm{pH}$, salinity, temperature, $\mathrm{NH}_{3}-\mathrm{N}, \mathrm{Ca}, \mathrm{Mg}, \mathrm{SO}_{4}^{2-}$ and $\mathrm{Mn}$. This 
provided insight on the chemical changes in relation to discharge of waste water into the river and hydro-geochemical processes within the river system [14] [30].

The strong factor loadings on colour, turbidity, TSS, TDS, E.C, salinity, $\mathrm{SO}_{4}^{2-}, \mathrm{Mg}$ and $\mathrm{Ca}$ was an indication of the influence erosion and waste water on the river hydrochemistry. The strong factor loading on $\mathrm{Ca}, \mathrm{Mg}, \mathrm{SO}_{4}^{2-}, \mathrm{Mn}$, and salinity revealed the influx of considerable amount of inorganic pollutants into the river water. Dissolved $\mathrm{SO}_{4}^{2-}$ with positive factor loading was as a result of oxidation of organic and inorganic sulphur compounds brought into the river by erosion and waste discharge into the aquatic environment. The seasonal variation of $\mathrm{SO}_{4}^{2-}$ could also be attributable to changes in the intensity of the weathering process. $\mathrm{NH}_{3}-\mathrm{N}$ with strong factor loading value was a demonstrator that the influx of nitrogenous organic wastes into river caused extra seasonal variation in river water quality.

Factor 2 accounted for about $30.8 \%$ of the total variance. The parameters with strong factor loading values in this factor and the most important in water quality variation were $\mathrm{Fe}, \mathrm{pH}, \mathrm{COD}, \mathrm{BOD}, \mathrm{DO}$, alkalinity and total hardness. This was a demonstrator that there is entry of organic and inorganic waste from domestic waste water, raw sewage, as well as industrial effluents, with considerable pollution. This caused extra variation in river water quality more times of the study. The result has demonstrated that $\mathrm{Fe}, \mathrm{Mn}, \mathrm{Ca}$, and $\mathrm{Mg}$ may not necessarily be as a result of anthropogenic inputs but may also be due to the soil /sediment characteristics over which the river water flows.

The $\mathrm{BOD}_{5}$ and $\mathrm{COD}$ with strong factor loadings were due to entry of waste water effluent and raw sewage, which caused considerable pollution. This was explanatory of the fact that there was entry of domestic waste, industrial waste and raw sewage into the river. Therefore, a close inspection of Eigen values, factor loadings, and significant water quality parameters in each season revealed that besides geochemical phenomena, seasonal regime of the River Rwizi water is controlled by two important hydrological and anthropogenic processes. There are other reports [15] [16] [29] [31] [35] [37] with comparable results in seasonal water quality evaluation.

\section{Conclusions}

In this study, seasonal variation in surface water quality was assessed by using PCA/FA. The results revealed that water pollution resulted primarily from domestic waste water, agricultural runoff, industrial effluents and natural hydrologic processes. All the study sites recorded iron, $\mathrm{COD}$ and $\mathrm{pH}$ (rain season) above allowable maximum limit in surface water. Also some sites showed higher manganese, BOD and TDS than the standards.

The principal component analysis and factor analysis were used to extract and recognize the factors or origins responsible for water quality variations in the two seasons of the year. PCA/FA determined that $81.2 \%$ of the total variance was explained by the first factor for the dry season and $69.2 \%$ for rain season. Consequently, it was important that when choosing water quality parameters for im- 
plementing environmental monitoring strategies in river basins, the seasonal variations of the parameters in assessment of water quality must be taken into account. This study demonstrated the importance of multivariate statistics for analysis of complex water quality data sets and their interpretation. It also assists in identification of pollution sources. The results provide a better understanding of seasonal variations in water quality of river water systems.

\section{References}

[1] Zhou, F., Huang, G.H., Guo, H.C., Zhang, W. and Hao, Z.J. (2007) Spatio-Temporal Patterns and Source Apportionment of Coastal Water Pollution in Eastern Hongkong. Water Research, 41, 3429-3439. https://doi.org/10.1016/j.watres.2007.04.022

[2] Helena, B., Pardo, R., Vega, M., Barrado, E., Fernandez, J.M. and Fernandez, L. (2000) Temporal Evaluation of Ground Water Composition in an Alluvial Aquifer (Pisuerga River,Spain) by Principal Component Analysis. Water Research, 34, 807-816. https://doi.org/10.1016/S0043-1354(99)00225-0

[3] Ouyang,Y., Nkedi Kizza, P., Wu, Q.T., Shinde, D. and Huang, C.H. (2006) Assessment of Seasonal Variations in Surface Water Quality. Water Research, 40, 3800 3810. https://doi.org/10.1016/j.watres.2006.08.030

[4] Kansiime, F., Kateyo, E. and Okot-Okumu, J. (1995) Effects of Pollution on Inner Murchison Bay (Lake Victoria-Uganda) on the Distribution and Abundance of Plankton. A Report of Makerere Institute of Environment and Natural Resources.

[5] Kansiime, F. and Nalubega, M. (1999) Wastewater Treatment by Natural Wetland: The Nakivubo Swamp, Uganda. Processes and Implementations. Ph.D. Dissertation, Wageningen Agricultural University, Wageningen, Netherlands.

[6] Nyangababo, J.T., Henry, I. and Omutunge, E. (2005) Heavy Metal Contamination in Plants, Sediments, and Air Precipitation of Katonga, Simiyu and Nyando Wetlands of Lake Victoria Basin, East Africa. Bulletin of Environmental Contamination and Toxicology, 75, 189-196. https://doi.org/10.1007/s00128-005-0737-5

[7] Muwanga, A. and Barifaijo, E. (2006) Impact of Industrial Activities on Heavy Metal Loading and their Physico-Chemical Effects on Wetlands of Lake Victoria Basin (Uganda). African Journal of Science and Technology (AJST), Science and Engineering Series, 7, 51-63.

[8] Sekabira, K., Oryem-Origa, H., Basamba, T.A., Mutumba, G. and Kakudidi, E. (2010) Assessment of Heavy Metal Pollution in the Urban Stream Sediments and Its Tributaries. International Journal of Environmental Science \& Technology, 7, 435-446. https://doi.org/10.1007/BF03326153

[9] Langelier, W.F. (1946) Chemical Equilibria in Water Treatment. Journal of American Water Works Association, 38, 35.

[10] Efe, S.I., Ogban, F.E., Horsfall, M. and Akporhonor, E.E. (2005) Seasonal Variations of Physico-Chemical Characteristics in Water Resources Quality in Western Niger Delta Region, Nigeria. Journal of Applied Sciences and Environmental Management, 9, 191-195.

[11] Cobbina, J.S., Armah, A.F. and Obiri, S. (2012) Multivariate Statistical and Spatial Assessment of Ground Water Quality in the Tolon-Kumbungu District, Ghana. Research Journal of Environmental and Earth Sciences, 4, 88-98.

[12] Mazlum, N., Ozer, A. and Mazlum, S. (1999) Interpretation of Water Quality Data by Principal Component Analysis. Turkish Journal of Engineering and Environ- 
mental Sciences, 23, 19-26.

[13] Kim, J.H., Kim, R.H., Lee, J., Cheong, T.J., Yum, B.W. and Chang, H.W. (2005) Multivariate Statistical Analysis to Identify the Major Factors Governing Ground Water Quality in the Coastal Area of Kimje, South. Hydrological Processes, 19, 1261-1276. https://doi.org/10.1002/hyp.5565

[14] Bu, H., Tan, X., Li, S. and Zhang, Q. (2010) Temporal and Spatial Variations of Water Quality in the Jinshu River of the South Qinling Mts., China. Ecotoxicology and Environmental Safety, 73, 907-913.

[15] Yerel, S. and Ankara, H. (2012) Application of Multivariate Statistical Techniques in the Assessment of water Quality in Sakarya River, Turkey. Journal of Geological Society of India, 79, 89-93. https://doi.org/10.1007/s12594-012-0019-x

[16] Yousefi, Z., Tarassoli, A., Nasirahmadi, K., Yaghobzadeh, Y. and Yadohalli, A. (2013) Assessment of the Surface Water Quality in Tajan River Basin, Iran. Life Science Journal, 10, 775-780.

[17] Kazi, T.G., Arain, M.B., Jamali, M.K., Jalbani, N., Afridi, H.I., Sarfaz, R.A., Baig, J.A. and Shah, A.Q. (2000) Assessment of Water Quality of Polluted Lake Using Multivariate Statistical Techniques: A Case Study. Ecotoxicology and Environmental Safety, 72, 301-309.

[18] Mukwaya, C. and Mugabe, R. (2010) Cooperation in Management of Water Resources in the Rwizi Catchment, Southwestern Uganda: A Study for the Directorate of Water Resources Management. Ministry of Water and Environment, Entebbe.

[19] Kyosingira, F.W., Mwesigwa, D.N., Twikirize, D. and Twinomuhangi, M. (2011) The Declining Trends of Water Resources in Uganda; A Case Study of River Rwizi, Lake Wamala, Lake Victoria Catchments and Representative Ground Water Monitoring Stations. Water Resources Monitoring and Assessment Division, Department of Monitoring and Assessment, Directorate of Water Resources Management, Entebbe.

[20] American Public Health Authority (1998) Standard Methods for the Examination of Water and Water. 20th Edition, APHA/AWWA/WEF, Washington DC.

[21] Vogel, I.A. and John, M. (2000) Vogel's Textbook of Quantitative Chemical Analysis. 6th Edition, Prentice-Hall, London.

[22] Hach Company (1992) Water Analysis Handbook. 2nd Edition, Hach Company, Loveland, Colorado, USA, 303, 669-3050.

[23] Alvin, C.R. (2002) Methods of Multivariate Analysis. John Wiley, Hoboken.

[24] Richard, A.J. and Dean, W.W. (2002) Applied Multivariate Statistical Analysis. Prentice Hall, London.

[25] Shrestha, S. and Kazama, F. (2007) Assessment of Surface Water Quality Using Multivariate Statistical Techniques: A Case Study of the Fuji River Basin, Japan. Environmental Modelling \& Software, 22, 464-475. https://doi.org/10.1016/j.envsoft.2006.02.001

[26] Yu, S., Shang, J., Zhao, J. and Guo, H. (2003) Factor Analysis and Dynamics of Water Quality of the Shonghua River North East China. Water, Air, \& Soil Pollution, 144,159-169. https://doi.org/10.1023/A:1022960300693

[27] Liu, C.W., Lin, K.H. and Kuo, Y.M. (2003) Application of Factor Analysis in a Black Foot Disease Area in Taiwan. Science of the Total Environment, 313, 77-89. https://doi.org/10.1016/S0048-9697(02)00683-6

[28] Juahir, H., Zain, S.M., Yusoff, M.K., Hanidza, T.I.T., Armi, A.S.M., Toriman, M.E. and Mokhtar, M. (2010) Spatial Water Quality Assessment of Langat River Basin (Malaysia) Using Environmetric Techniques. Environmental Monitoring and As- 
sessment, 173, 625-641. https://doi.org/10.1007/s10661-010-1411-x

[29] Zare Garizi, A., Shiekh, V. and Sadoddin, A. (2011) Assessment of Seasonal Variations of Chemical Characteristics in Surface Water Using Multivariate Statistical Methods. International Journal of Environmental Science and Technology, 8, 581592. https://doi.org/10.1007/BF03326244

[30] Etim, U.E. and Adie, U.G. (2012) Assessment of Surface Water, Sediments and Aquatic Fish from Selected Major Rivers in South-Western Nigeria. Research Journal of Environmental and Earth Sciences, 4, 1045-1051.

[31] Pejman, A.H., Nabbi Bidheni, G.R., Karbassi, A.R., Mehrdadi, N. and Esmaeli Bidheni, M. (2009) Evaluation of Spatial and Seasonal Variation in Surface Water Quality Using Multivariate Statistical Techniques. International Journal of Engineering Science and Technology, 6, 467-476. https://doi.org/10.1007/bf03326086

[32] NEMA (National Environment Management Authority) (1999) Standards for Discharge of Effluent or Waste Water. Maximum Permissible Limits. S.I No. 5/1999.

[33] NIS (Nigerian Industrial Standards) (2007) Nigerian Standard for Drinking Water Quality. NIS554, 2007, ICS 13.060.20, Approved by the Standard Organisation of Nigeria (SON) Governing Council, 14-18.

[34] World Health Organization (2004) Guidelines for Drinking Water Quality. 3rd Edition, Vol. 1, Recommendations, World Health Organisation, Geneva.

[35] Singh, K.P., Malik, A., Mohan, D. and Sinha, S. (2004) Multivariate Statistical Techniques for the Evaluation of Spatial and Temporal Variations in Water Quality of Gomti River (India). A Case Study. Water Research, 38, 3980-3992.

https://doi.org/10.1016/j.watres.2004.06.011

[36] Najafpour, S., Alkari, A.F.M., Kadir, M.O.A. and Najafpour, G.D. (2008) Evaluation of Spatial and Temporal Variation in River Water Quality. International Journal of Environmental Research, 2, 349-358.

[37] Dike, N.K., Ajibola, V.O., Ezealor, A.U. and Oriye, S.J. (2013) Spatial Assessment of Metals along River Jakara, Kano Using Multivariate Statistical Techniques. International Journal of Research in Environmental Science and Technology, 3, 130-134.

Submit or recommend next manuscript to SCIRP and we will provide best service for you:

Accepting pre-submission inquiries through Email, Facebook, LinkedIn, Twitter, etc. A wide selection of journals (inclusive of 9 subjects, more than 200 journals)

Providing 24-hour high-quality service

User-friendly online submission system

Fair and swift peer-review system

Efficient typesetting and proofreading procedure

Display of the result of downloads and visits, as well as the number of cited articles

Maximum dissemination of your research work

Submit your manuscript at: http://papersubmission.scirp.org/

Or contact jwarp@scirp.org 